\title{
Protective Function of Butylated Hydroxytoluene in Lead-Induced Oxidative Alterations in Tissues of Wistar Rats
}

\author{
*OBIWULU, ENO \\ Department of Integrated Science, Delta State College of Education, Agbor, Nigeria \\ *Corresponding Authority Email: estherobiwulu2@gmail.com Tel: +234(0)8034220087
}

\begin{abstract}
This study was designed to evaluate the protective function of butylated hydroxytoluene (BHT) in $\mathrm{Pb}$ induced oxidative damage to blood, hepatic and renal tissues of exposed rats. Four groups (I-IV) with six male Wistar rats each, were considered in this study, where group I rats (control) received $1 \mathrm{ml}$ of corn oil, group II received intraperitoneally $30 \mathrm{mg} \mathrm{PbCl} / 2 \mathrm{~kg} \mathrm{~b}$. wt of rats only, group III rats were administered with NOAEL of BHT at $25 \mathrm{mg} / \mathrm{kg}$ and group IV rats were administered intraperitoneal injection of $30 \mathrm{mg} \mathrm{PbCl} 2$ plus oral administration of $25 \mathrm{mg}$ BHT dispersed in corn oil per $\mathrm{kg} \mathrm{b}$. wt of the rats for 28 days with the evaluation of oxidative stress biomarkers in the tissues. $\mathrm{Pb}$ significantly increased tissue MDA levels in group II rats, but BHT reduced MDA levels in tissues for groups III and IV rats at $\mathrm{p}<0.05$ relative to control. In serum, biomarkers (GSH: $1.46 \pm 0.08 \mu \mathrm{g} / \mathrm{mg}$ protein; CAT: $63.74 \pm 0.20 \mathrm{units} / \mathrm{mg}$ protein; SOD: $16.49 \pm 0.39$ units/mg protein and GPx: $12.84 \pm 0.17$ units/mg protein) exhibited significant reduction $(\mathrm{p}<0.05)$ in group II rats, but were significantly stimulated in groups III and IV rats relative to group I rats. Similar trends were observed in hepatic and renal tissues. Therefore, the present study successfully established the functional role of $\mathrm{BHT}$ in the amelioration of $\mathrm{Pb}$-induced oxidative stress in exposed rats.
\end{abstract}

\section{DOI: https://dx.doi.org/10.4314/jasem.v23i11.23}

Copyright: Copyright (C 2019 Obiwulu. This is an open access article distributed under the Creative Commons Attribution License (CCL), which permits unrestricted use, distribution, and reproduction in any medium, provided the original work is properly cited.

Dates: Received: 04 October 2019; Revised: 11 November 2019; 23 November 2019

Keywords: Antioxidant, Biomarkers, Butylated hydroxytoluene, Oxidative stress, Lead toxicity

The affirmation of lead $(\mathrm{Pb})$ as an environmental toxicant to humans and other biological systems may not be unconnected with its anthropogenic usefulness at domestic, industrial and agricultural levels respectively. $\mathrm{Pb}$, as a known heavy metal, is chiefly distributed in the earth's crust with serious public concerns, especially when in contact with biological systems along the food chain (Valko et al., 2005). Upon extraction of the metal from its ores, it is often difficult to destroy or render it harmless; hence, the need to avoid its overuse as well as safe disposition of the toxic metal is extremely important in toxicological sciences. $\mathrm{Pb}$ poisoning was reported to occur through ingestion of contaminated foods and water supplied through lead pipes, where it is acted upon by intestinal secretions to convert it to its salt form, absorbed into the blood stream and distributed to tissues with cumulative toxic effects (Bandyopadhyay et al., 2014). It is important to note that diverse sources of exposure, (mining and metallurgy, municipal inclinator workers, workers in battery manufacturing plants, construction workers, ceramics industry workers, paint industry workers, automobile fuels, etc.), to humans have been associated with $\mathrm{Pb}$ toxicity, which may be acute, subacute or chronic effects (Bandyopadhyay et al., 2014; Sharma et al., 2014; Ujowundu et al., 2017; Obafemi et al., 2019). The accumulation of lead $(\mathrm{Pb})$ metal above tolerable level in biological systems may results in lifethreatening consequences. Today, $\mathrm{Pb}$ is one of the most common toxic heavy metals known to contaminate soil, water and air due to increased industrialization and brought about by anthropogenic activities (WHO, 2010; Obafemi et al., 2019). The accumulation of this metal occurs along the food chain, where the consumers are prone to its toxicity. Studies have shown that the bioaccumulation of $\mathrm{Pb}$ in tissues instigates excessive synthesis of reactive oxygen species (ROS) to an overwhelming state of the in vivo antioxidant defence system, and this phenomenon is termed "oxidative stress" (Flora et al., 2008; Sharma et al., 2014). It was further highlighted in reports that excessive production of ROS results in the disruption of physiological, biochemical and a host of other cellular functions, occurring in complex biological systems (Gupta et al., 2015). Thus, Pbinduced oxidative stress has been implicated in protein oxidation through its affinity for sulfhydryl groups, development of DNA damage and lipid peroxidation process (Valko et al., 2005; Ujowundu et al., 2017). The toxic effects of $\mathrm{Pb}$ on hepatic, renal, digestive, skeletal, cardiovascular, reproductive, hematopoietic and nervous systems were reported to be mediated or associated with increased oxidative stress (Kalia and Flora, 2005). A unique mechanism of action of $\mathrm{Pb}$ toxicity in exposed multicellular 
organisms was its increased affinity for sulfhydryl groups present in both enzymatic and non-enzymatic antioxidants with inactivation of catalase and superoxide dismutase activities, and consequential reduction of glutathione levels through inhibition of glutathione-related antioxidant enzymes (Hultberg et al., 2001; Ahamed and Siddiqui, 2007). This mechanistic action of $\mathrm{Pb}$ toxicity was also implicated in the inhibition of enzymes associated with heme synthetic pathway as well as reduction of life span of circulating red blood cells (RBCs), leading to the development of anemia (Guidotti et al., 2008; Bandyopadhyay et al., 2014). However, Pietta (2000) reported the significant roles played by antioxidants, especially during supplementation of diet, to ameliorate and prevent ROS-induced oxidative stress, and to enhance in vivo antioxidant defence system. To this end, the use of butylated hydroxytoluene (BHT), as a known antioxidant (Elgazar, 2013), cannot be over-emphasized in the current study.

In conceptual framework, BHT, which is chemically known as "2,6-di-tert-butyl-p-kresol or 2,6-di-tertbutly-4-methylphenol," is a synthetic antioxidant employed in the preservation of fat-rich foods as well as cosmetic products, where it scavenges free radicals known to initiate lipid oxidation thereby stopping deterioration process (Lanigan and Yamarik, 2002). BHT was reported to be a safe food additive with $0.5 \mathrm{mg} / \mathrm{kg}$ body weight acceptable daily intake for man. Upon ingestion, it is readily absorbed from the gastrointestinal tract into the blood stream, where it is distributed to tissues, particularly hepatic tissues. It is primarily metabolized in the microsomes of hepatic tissues to sulfate and glucuronic acid conjugates, which are in turn excreted in urine, faeces and bile respectively (Panicker et al., 2014). The toxicological review on BHT using various animal models shows that its $\mathrm{LD}_{50}$ exceeds $2930 \mathrm{mg} / \mathrm{kg}$ during its oral administration. Besides its antioxidant role, Devi et al. (2003) reported that BHT causes liver enlargement, hepatocellular vacuolation, liver necrosis, peliosis, induction of reversible mixed function oxidases and haemorrhagic death in rats and mice at high concentrations. Therefore, the present study was designed to ascertain the protective function of BHT in $\mathrm{Pb}$-induced oxidative changes in the tissues of male Wistar rats.

\section{MATERIALS AND METHODS}

Chemicals/Reagents: An array of chemicals employed in the current study was of analytical and qualitative considerations.

Experimental Animals: Twenty-four male Wistar rats, weighing 150-208 $\mathrm{g}$ were purchased from the
Department of Biochemistry, University of Benin, Nigeria for the study. They were housed allowed to acclimatize for two weeks and maintained under standard laboratory conditions (room temperature of $27 \pm 2^{\circ} \mathrm{C}$, relative humidity of $46 \pm 1 \%$ and a 12 12 hour light-dark cycle). They had free access to rat chows and water ad libitum. The college ethics committee approved the experimental process in this study.

Experimental Design: The experimental protocol was based on two scientific reports in which it was established by Ansar (2016) that a single intraperitoneal injection of $30 \mathrm{mg} / \mathrm{kg}$ of $\mathrm{PbCl}_{2}$ causes the induction of oxidative stress in Wistar rats, and the European Food Safety Authority (EFSA) established in a series of studies that the use of BHT in foods, as an authorized synthetic antioxidant, showed noobserved adverse effect level (NOAEL) at $25 \mathrm{mg} / \mathrm{kg}$ body weight per day in exposed rats (EFSA, 2012).. After two weeks of acclimatization, four experimental groups (labelled I-IV) with six animals each were obtained based on their closely related body weights. Group I, which served as the control vehicle, received $1 \mathrm{ml}$ of corn oil by oral route using a gavage. Based on the NOAEL, BHT was dissolved in corn oil and administered orally per day by means of a gavage for twenty-eight days to group III only as well as Group IV rats, which were induced by single intraperitoneal injection of $30 \mathrm{mg} \mathrm{PbCl} / \mathrm{kg}$ body weight. Similarly, group II rats were induced intraperitoneally with $30 \mathrm{mg} \mathrm{PbCl} / 2 \mathrm{~kg}$ body weight of rats only.

Experimental Sampling: After overnight fast, the rats were sacrificed by heart puncture such that blood samples were collected into EDTA bottles and further centrifuged at $2500 \mathrm{~g}$ for 10 minutes to obtain their supernatants. Also liver and kidney tissues were excised into plain containers containing normal saline. Exactly $10 \%(\mathrm{w} / \mathrm{v})$ of liver and kidney tissues was homogenized in $10 \mathrm{ml}$ of $0.05 \mathrm{M}$ phosphate buffer ( $\mathrm{pH}$ 7.4) and centrifuged at $10,000 \mathrm{~g}$ for 20 minutes. All supernatants were refrigerated at $4^{\circ} \mathrm{C}$ for further analysis.

Assessment of Stress Biomarkers: The concentration of thiobarbituric acid reactive substance or malondialdehyde (TBARS/MDA) level in sample was estimated by the method of Iqbal et al. (1996). Superoxide dismutase (SOD) activity was evaluated using spectrophotometric method (Misra and Fridovich,1972) based on the auto-oxidation of adrenaline to form adrenochrome. Catalase (CAT) activity was assessed following the methods of Aebi (1974) and Luck (1984) based on the quantification of hydrogen peroxide consumed after the enzymatic 
reaction. Glutathione-s-transferase (GST) activity will be evaluated by the procedure outlined by Habig et al. (1974) based on the extent of conjugation of reduced glutathione (GSH) with chloro-2,4dinitrobenzene (CDNB) and glutathione peroxidase (GPx) activity was estimated following the method of Paglia et al. (1979). As a non-enzymatic antioxidant, reduced glutathione (GSH) level in each sample was evaluated based on its reaction with Ellman's reagent by the method of Moron et al. (1979).

Statistical Analysis: Data were expressed as mean \pm SEM (=standard error of mean). Statistical significance of the results obtained for various groups was employed through one way analysis of variance (ANOVA) followed by tukey's multiple comparison (TMC) test, and the level of significance was set at $p$ $<0.05$.

\section{RESULTS AND DISCUSSION}

The pervasive nature of lead $(\mathrm{Pb})$ in the environment necessitates public health concerns due to its associated toxicity to predisposed biological systems. This may be initiated by increased industrialization as a result of anthropogenic activity. The study revealed significant changes $(p<0.05)$ in MDA level in the tissues of exposed rats to $\mathrm{BHT}$ and $\mathrm{Pb}$ treatments (Table 1). In the blood, liver and kidney tissues of exposed rats, the intraperitoneal injection of $30 \mathrm{mg} \mathrm{Pb} / \mathrm{kg}$ b.wt of rats significantly raised $(\mathrm{p}<0.05)$ MDA level in group II rats relative to control (group I). This marked the induction of oxidative stress in the tissues of experimental animals. However, the oral administration of $25 \mathrm{mg} \mathrm{BHT} / \mathrm{kg}$ to groups III and IV rats resulted in significant reduction $(\mathrm{p}<0.05)$ in MDA levels in the respective tissues of exposed rats when compared with group I rats (control). This may indicate the protective role of $\mathrm{BHT}$ in $\mathrm{Pb}$-induced oxidative stress in group IV exposed rats. Reports have shown that $\mathrm{Pb}$ toxicity is characterized by physiological and metabolic alterations at the cellular and molecular levels with the onset of disease condition in exposed rats (Atef et al., 2013; Ujowundu et al., 2017; Obafemi et al., 2019). The development of these pathologies in exposed biological systems was characterized with oxidative stress, which was evidently observed in the present study (Table 1) for respective tissues of exposed rats to intraperitoneal injection of $30 \mathrm{mg} \mathrm{\textrm {PbCl } _ { 2 }}$. $\mathrm{Pb}-$ instigated oxidative stress was reported to be deeplyrooted in lipid peroxidation process in which MDA is a stable biomarker (Bechara, 2004). The study further highlighted that the excessive formation of MDA may be due to over-expression of ROS and capacity to target sulfhydryl groups during undue exposure to environmental stressors. However, the study established that the presence of BHT at NOAEL in group III and IV rats was able to significantly reduce MDA levels in blood, liver and kidney tissues in relation to groups I and II rats (Table 1). This development can be corroborated with earlier reports that BHT, which is commonly used in foods as a safe additive with antioxidant potential, has the capacity to inhibit lipid peroxidation (Sasse et al., 2009; Elgazar, 2013). This confirmed its role as free radical scavenger against lipid oxidation occurring in foods with the prevention of deterioration.

Table1. Effects of BHT and $\mathrm{Pb}$ on MDA levels in tissues of exposed rats

\begin{tabular}{lllll}
\cline { 2 - 4 } \multicolumn{2}{l}{$\begin{array}{l}\text { Experimental } \\
\text { Groups }\end{array}$} & \multicolumn{2}{c}{ TRARS/MDA Level in (expressed as nmoles/g) Tissue Samples } \\
\cline { 2 - 4 } & Blood & Liver & Kidney \\
\hline I & $5.69 \pm 0.16^{\mathrm{a}}$ & $13.36 \pm 0.20^{\mathrm{a}}$ & $8.35 \pm 0.13^{\mathrm{a}}$ \\
II & $17.64 \pm 0.28^{\mathrm{b}}$ & $20.05 \pm 0.59^{\mathrm{b}}$ & $13.16 \pm 0.38^{\mathrm{b}}$ \\
*Experimental results & III & $4.90 \pm 0.09^{\mathrm{a}}$ & $8.88 \pm 0.37^{\mathrm{c}}$ & $5.55 \pm 0.23^{\mathrm{c}}$ \\
\cline { 2 - 4 } & IV & $9.20 \pm 0.19^{\mathrm{c}}$ & $16.26 \pm 0.16^{\mathrm{d}}$ & $10.16 \pm 0.10^{\mathrm{d}}$ \\
\hline
\end{tabular}

Table 2. Effect of BHT and Pb toxicity on non-enzymatic and enzymatic antioxidants in the serum of exposed Wistar rats

\begin{tabular}{lllll}
\hline Biomarkers & \multicolumn{2}{l}{ Experimental Groups } & \\
\cline { 2 - 5 } & I & II & III & IV \\
\hline GSH & $2.48 \pm 0.08^{\mathrm{a}}$ & $1.46 \pm 0.08^{\mathrm{b}}$ & $6.11 \pm 0.25^{\mathrm{c}}$ & $5.12 \pm 0.15^{\mathrm{d}}$ \\
CAT & $86.46 \pm 0.88^{\mathrm{a}}$ & $63.74 \pm 0.20^{\mathrm{b}}$ & $123.70 \pm 0.29^{\mathrm{c}}$ & $86.31 \pm 0.54^{\mathrm{a}}$ \\
SOD & $23.67 \pm 0.17^{\mathrm{a}}$ & $16.49 \pm 0.39^{\mathrm{b}}$ & $25.30 \pm 0.25^{\mathrm{c}}$ & $22.88 \pm 0.15^{\mathrm{a}}$ \\
GPx & $18.32 \pm 0.21^{\mathrm{a}}$ & $12.84 \pm 0.17^{\mathrm{b}}$ & $26.23 \pm 0.57^{\mathrm{c}}$ & $21.75 \pm 0.23^{\mathrm{d}}$ \\
\hline
\end{tabular}

* Experimental results were expressed as Mean \pm SEM (=standard error of mean) of six determinations $(n=6)$. Mean values with different letters differ significantly $(p<0.05)$ across each row. The activities of enzymatic antioxidants were expressed as units per milligram protein in tissue and GSH level was expressed as microgram per milligram protein of tissue respectively.

Table 2 explains the effects of BHT and $\mathrm{Pb}$ toxicity on non-enzymatic and enzymatic antioxidants in the tissues of exposed rats. The intraperitoneal administration of $30 \mathrm{mg} \mathrm{Pb} / \mathrm{kg} \mathrm{b}$. wt of rats caused a significant reduction $(\mathrm{p}<0.05)$ in serum GSH level in group II rats, as compared with group I rats (control). 
However, the oral administration of BHT at NOAEL to group III rats only as well as to group IV rats pretreated with $30 \mathrm{mg} \mathrm{Pb} / \mathrm{kg}$ b.wt of the rats significantly raised serum GSH level when compared with the control group. In relation to group I (control), there was significant inhibition $(\mathrm{p}<0.05)$ of serum CAT, SOD and GPx activities in group II rats induced with $30 \mathrm{mg} \mathrm{Pb} / \mathrm{kg}$ intraperitoneally, but this was significantly relieved in group IV rats co-treated orally with BHT at NOAEL. Although no significant difference $(\mathrm{p}>0.05)$ was observed among the serum enzymatic antioxidants assessed in groups I (control) and IV rats, but there was marked increase $(p<0.05)$ in serum antioxidant CAT, SOD and GPx activities in group IV rats relative to group II rats. Thus, BHT may be a useful enhancer of serum antioxidant defence system of rats exposed to $\mathrm{Pb}$ toxicity.

The protective function of BHT on hepatic enzymatic and non-enzymatic antioxidants in rats exposed to $\mathrm{Pb}$ toxicity is shown in Table 3. Hepatic GSH levels were significantly reduced $9 p<0.05$ ) in group II rats exposed to $30 \mathrm{mg} \mathrm{Pb} / \mathrm{kg}$ in relation to group I rats (control). The oral administration of BHT to group III rats at NOAEL showed a marked increase $(p<0.05)$ in hepatic GSH levels. There was no significant difference $(\mathrm{p}>0.05)$ between hepatic GSH levels assessed in groups I and IV rats, but hepatic GSH level significantly increased $(p<0.05)$ in group IV rats exposed to $\mathrm{BHT}$ and $\mathrm{Pb}$ when compared with group II rats exposed to $30 \mathrm{mg} / \mathrm{kg}$ of intraperitoneal injection of only $\mathrm{Pb}$ compound. In group II rats treated with 30 $\mathrm{mg} \mathrm{PbCl} / 2 \mathrm{~kg} \mathrm{~b}$. wt of the animal resulted in significant inhibition of hepatic CAT, SOD and GPx activities. The inhibitory effect observed on enzymatic antioxidants in hepatic tissues of group II rats was relieved in group IV rats upon oral administration of BHT at NOAEL throughout the experimental period. Although there was no significant alteration in hepatic CAT activity in group IV rats relative to group I (control), but utmost concern may be comparatively observed in the activity of hepatic CAT group IV rats relative to group II rats. This development may justify the protective function of $\mathrm{BHT}$ on $\mathrm{Pb}$-induced oxidative damage in exposed rats.

Table 3. Effect of BHT and Pb toxicity on non-enzymatic and enzymatic antioxidants in the hepatic tissues of exposed Wistar rats

\begin{tabular}{lllll}
\hline Biomarkers & \multicolumn{2}{l}{ Experimental Groups } & IV \\
\cline { 2 - 5 } & I & II & III & IV I $^{\mathrm{c}}$ \\
\hline GSH & $9.16 \pm 0.18^{\mathrm{a}}$ & $6.84 \pm 0.07^{\mathrm{b}}$ & $11.11 \pm 0.20^{\mathrm{a}}$ & $9.43 \pm 0.10^{\mathrm{a}}$ \\
CAT & $42.69 \pm 0.89^{\mathrm{a}}$ & $28.26 \pm 0.50^{\mathrm{b}}$ & $75.55 \pm 0.58^{\mathrm{c}}$ & $55.04 \pm 0.61^{\mathrm{d}}$ \\
SOD & $18.24 \pm 0.13^{\mathrm{a}}$ & $15.21 \pm 0.16^{\mathrm{b}}$ & $25.36 \pm 0.17^{\mathrm{c}}$ & $22.85 \pm 0.11^{\mathrm{d}}$ \\
GPx & $15.47 \pm 0.24^{\mathrm{a}}$ & $13.00 \pm 0.12^{\mathrm{b}}$ & $36.08 \pm 0.52^{\mathrm{c}}$ & $22.50 \pm 0.22^{\mathrm{d}}$ \\
\hline
\end{tabular}

*Experimental results were expressed as Mean \pm SEM (=standard error of mean) of six determinations $(n=6)$. Mean values with different letters differ significantly $(p<0.05)$ across each row. The activities of enzymatic antioxidants were expressed as units per milligram protein in tissue and GSH level was expressed as microgram per milligram protein of tissue respectively.

The functional role of BHT in renal antioxidant defence system during $\mathrm{Pb}$-induced oxidative damage is explained in Table 4. Intraperitoneal administration of $\mathrm{Pb}$ at $30 \mathrm{mg} / \mathrm{kg}$ caused renal reduction $(\mathrm{p}<0.05)$ of GSH level in group II rats in relation to group I rats (control) while oral administration of BHT at NOAEL caused a significant increase $(\mathrm{p}<0.05)$ in renal GSH levels in groups III and IV rats relative to groups I and II rats. Similarly, $\mathrm{Pb}$ significantly reduced $(p<0.05)$ the activities of CAT, SOD and GPX in the renal tissues of exposed group II rats when compared with group I rats. In comparison with group II rats, renal CAT, SOD and GPx activities showed significant increase in group IV rats due to the antioxidant property of BHT administered at NOAEL. In the absence of the toxic effect of the metal, BHT showed a stimulating effect on renal enzymatic antioxidants in group III rats relative to group I rats at $\mathrm{p}<0.05$. It may be culminated in this study that, BHT may be considered a potent antioxidant with stimulating effect and ameliorative function during $\mathrm{Pb}$-induced oxidative stress in exposed rats.

Table 4. Effect of $\mathrm{BHT}$ and $\mathrm{Pb}$ toxicity on non-enzymatic and enzymatic antioxidants in the renal tissues of exposed Wistar rats

\begin{tabular}{lllll}
\hline Biomarkers & \multicolumn{5}{l}{ Experimental Groups } & \\
\cline { 2 - 5 } & I & II & III & IV \\
\hline GSH & $0.48 \pm 0.01^{\mathrm{a}}$ & $0.38 \pm 0.01^{\mathrm{a}}$ & $2.07 \pm 0.06^{\mathrm{b}}$ & $1.38 \pm 0.03^{\mathrm{c}}$ \\
CAT & $32.05 \pm 0.28^{\mathrm{a}}$ & $22.85 \pm 0.20^{\mathrm{b}}$ & $52.87 \pm 0.57^{\mathrm{c}}$ & $34.21 \pm 0.40^{\mathrm{d}}$ \\
SOD & $12.14 \pm 0.07^{\mathrm{a}}$ & $8.67 \pm 0.13^{\mathrm{b}}$ & $14.91 \pm 0.11^{\mathrm{c}}$ & $12.36 \pm 0.11^{\mathrm{a}}$ \\
GPx & $8.98 \pm 0.19^{\mathrm{a}}$ & $5.96 \pm 0.25^{\mathrm{b}}$ & $19.15 \pm 0.38^{\mathrm{c}}$ & $11.42 \pm 0.18^{\mathrm{d}}$ \\
\hline
\end{tabular}

*Experimental results were expressed as Mean \pm SEM (=standard error of mean) of six determinations $(n=6)$. Mean values with different letters differ significantly $(p<0.05)$ across each row. The activities of enzymatic antioxidants were expressed as units per milligram protein in tissue and GSH level was expressed as microgram per milligram protein of tissue respectively. 
Oxidative stress is a defined consequence of heightened incidence of free radicals with aftermath adverse effects on antioxidant defence systems (Poljsak et al., 2013). The present study highlighted that reduced GSH kevel as well as SOD, CAT and GSPx activities in blood, hepatic and renal tissues were significantly inhibited in group II rats exposed to intraperitoneal injection of $30 \mathrm{mg} \mathrm{PbCl}_{2} / \mathrm{kg}$ body weight of rats (Tables 2-4), but they were relieved during co-treatment with BHT for group IV rats in the respective tissues. As biomarkers for monitoring $\mathrm{Pb}$-induced oxidative changes, their depletions during over-exposure to this toxicant, which agrees with earlier reports, may be on the basis of its capacity to replace and inactivates the cofactors of the respective antioxidants (Flora et al., 2012; Offor et al., 2017). Furthermore, the results of this study agrees with the study carried out by Patra and his colleagues to suggest that exposure to $\mathrm{Pb}$ toxicity alters the functions of antioxidant enzymes, especially CAT, SOD, GPx and other metabolic enzymes of toxicological relevance, through the inhibition of functional-SH groups to form unstable mercaptide complexes (Patra et al., 2011). Ujowundu et al. (2017) also highlighted in their study that $\mathrm{Pb}$ toxicity alters the uptake of some trace elements (Zn, Se and $\mathrm{Cu})$ as cofactors required by some antioxidant enzymes (CAT, GPx and SOD) for adequate molecular structure and function respectively. In this study, this may account for the observable inhibitory effects on the antioxidant enzymes in group II rats relative to control group.

An epidemiological report revealed the competence of antioxidants to handle the damaging effects initiated by ROS, and to ameliorate the onsets of pathological conditions characterized by oxidative stress. However, a sustained synthesis of ROS can overwhelm and compromise the antioxidant defence system in prominent onset of pathologies (Godic et al., 2014). This explains the sustained synthesis of $\mathrm{ROS}$ in $\mathrm{Pb}$-exposed group II rats with associated inhibitory effects on enzymatic and non-enzymatic antioxidants. However, antioxidant supplementation using BHT was observed in the present study to improve $\mathrm{Pb}$-induced oxidative stress through enhanced antioxidant defence system of groups III and IV rats for the respective tissues (Tables 2-4). Suggestively, the proposed mechanisms of defence employed by the BHT-stimulated antioxidants, especially for group IV rats, may involve obstruction of ROS synthesis, transformation of $\mathrm{Pb}$-induced oxidants to less lethal molecules, and repairs of damaged tissues thereby conferring protection on biological systems through enhancement of the in vivo antioxidant defence system (Halliwell, 2007). To this end, the data obtained from group III rats treated with only BHT at NOAEL did not conform to the study carried out by Liu et al. (2007). This may probably be attributed to the difference in experimental setting: $25 \mathrm{mg} / \mathrm{kg}$ of BHT showed a stimulating effect on GSH and GPx activity in the tissues of rats, as observed in the present study while $1000-1500 \mathrm{mg} / \mathrm{kg}$ of BHT significantly inhibited GPx activity in earlier reports (Liu et al., 2007; Mean et al., 2017).

Conclusion: The data obtained in this study established the protective role of $\mathrm{BHT}$ in $\mathrm{Pb}$ instigated toxicity in Wistar rats. This was evident in the assessed biomarkers of oxidative stress during hepato-renal toxicity study of exposed experimental animals with significant improvement in both enzymatic and non-enzymatic antioxidants. Consequently, the efficacy of BHT, especially at NOAEL, may be highly suggested as an additive in food for the prevention and management of environmentally induced oxidative stress in exposed biological systems. Again, the present study considered BHT as a validated food additive with substantial capacity to annul $\mathrm{Pb}$ toxicity as well as to function as a potent stimulator of in vivo antioxidant defence system in predisposed biological systems.

\section{REFERENCES}

Aebi, H (1984). Catalase. In: Packer L (ed) Methods in enzymology, Academic press, Orlando, p 121126.

Ahamed, M; Siddiqui, MKJ (2007). Low level Lead exposure and oxidative stress: current opinions. Clinica Chimie Acta 383:57-64.

Ansar, S (2016). Evaluation of protective effect of rutin on lead acetate-induced testicular toxicity in Wistar rats. Toxin Rev. 34: 195-199.

Atef, M; Attia, M; Fatma, A; Ibrahim, A; Nabil, GM; Aziz, SW (2013). Antioxidant effects of ginger (Zingiber officinale Roscoe) against lead acetateinduced hepatotoxicity in rats. Afr. J. Pharm. Pharmacol. 7(20):1213-1219.

Bandyopadhyay, D; Ghosh, D; Chattopadhyay, A; Firdaus, SB; Ghosh, AK; Paul, S; Bhowmik, D; Mishra, S;

Dalui, K (2014). Lead induced oxidative stress: A health issue of global concern.. J. Pharm. Res., 8(9):1198-1207.

Bechara, EJH (2004). Lead poison and oxidative stress Free Radical Biol. Med. 36:22. 
Devi, RS; Shoba, N; Vijai, MK; Sabitha, K; Shyamala, E; Devi, CS (2003). Effect of a polyherbal formulation, Ambrex, on butylated hydroxy toluene (BHT) induced toxicity in rats. Indian J. Exp. Biol. 41: 1290-1294.

EFSA (European Food Safety Authority), (2012). Scientific opinion on the re-evaluation of butylated hydroxytoluene BHT (E 321) as a food additive. EFSA J. 10(3): 2588-2631.

Elgazar, A (2013). Effects of butylated hydroxytoluene and butylated hydroxyanisole against hepatotoxicity induced by carbon tetrachloride in rats. World Appl. Sci. J. 22 (1): 63-69.

Flora, G; Gupta, D; Tiwari, A (2012). Toxicity of lead: a review with recent updates. Interdiscip. Toxicol. 5: 47-58.

Flora, SJS; Chouhan, S; Kannan, GM; Mittal, M; Swarnkar, H (2008). Combined administration of taurine and monoisoamyl DMSA protects arsenic induced oxidative injury in rats. Oxid. Med. Cell. Longev. 1(1):39-45.

Godic, A; Poljsak, B; Adamic, M; Dahmane, R (2014). The role of antioxidants in skin cancer prevention and treatment. Oxid. Med. Cell. Longev. 14: 1-6.

Guidotti, TL; McNamara, J; Moses, MS (2008). The interpretation of trace element analysis in body fluids. Indian J. Med. Res. 128:524-32.

Gupta, VK; Pal, R; Siddiqi, NJ; Sharma, B (2015). Acetylcholinesterase from human erythrocytes as a surrogate biomarker of lead induced neurotoxicity. Enz. Res. 7: 34-43.

Habig, WH; Pabst, MJ; Jakoby, WB (1974). Glutathione-S-transferases: the first enzymatic step in mercapturic acid formation. J. Biol. Chem. 249: 7130-7139.

Halliwell, B (2007). Biochemistry of oxidative stress. Biochem. Soc.Transac. 35:1147-50.

Hultberg, B; Andersson, A; Isaksson, A (2001). Interaction of metals and thiols in cell damage and glutathione distribution: potentiation of mercury toxicity by dithiothreitol. Toxicol. 156:93-100.
Iqbal, M; Sharma, SD; Zadeh, HR; Hasan, N; Abdulla, M; Athar, M (1996). Glutathione metabolizing enzymes and oxidative stress in ferric nitrilotriacetate (Fe-NTA) mediated hepatic injury. Redox Report 2: 385-391.

Kalia, K; Flora, SJ (2005). Strategies for safe and effective therapeutic measures for chronic arsenic and lead poisoning. J. Occup. Health $47: 1-21$.

Lanigan, RS; Yamarik, TA (2002).. Final report on the safety assessment of BHT (1). Int. J. Toxicol. 21: 19-94.

Luck, H (1974). Methods in enzymatic analysis, Academic Press, New York.

Mean, S; Deger, T; Yildirim, S (2017). Effects of butylated hydroxytoluene on blood liver enzymes and liver glutathione and glutathione-dependent enzymes in rats. Bulgarian J. Vet.. Med. 10(20): $1-9$.

Misra, HP; Fridovich, I (1989). The role of superoxide anion in the auto-oxidation of epinephrine and simple assay for superoxide dismutase. J. Biol. Chem. 247: 3170-175.

Moron, MS; Despierre, JW; Minnervik, B (1979). Levels of glutathione, glutathione reductase and glutathione S-transferase activities in rat lung and liver. Biochim. Biophys. Acta 582: 67-78.

Obafemi, TO; Onasanya, A; Adeoye, A; Falode, JA; Daniel, DJ; Erefo, EF; Ojo, AO; Fadaka, A; Afolabi, OB; Awe, JO; Omiyale, BO (2019). Protective effect of methanolic and flavonoidrich leaf extracts of Synsepalum dulcificum (Danielli) on lead-acetate-induced toxicity in Wistar albino rats. J. Appl. Pharm. Sci. 9(5): 6572.

Offor,, SJ; Mbagwu, HOC; Orisakwe, OE (2017). Lead induced hepato-renal damage in male albino rats and effects of activated charcoal. Front. Pharmacol. 8: 107-126.

Paglia, DF;Valentaine, WN (1979). Studies on glutathione and glutathione characterization of erythrocytes glutathione peroxidase. J. Lab. Clin. Med. 70: 158-169.

Panicker, V; George, S; Krishna, BD (2014). Toxicity study of butylated hydroxyl toluene (BHT) in rats. World J Pharm. Pharm. Sci. 8: 758-763. 
Patra, RC; Rautray, AK; Swarup, D (2011). Oxidative stress in lead and cadmium toxicity and its amelioration. Vet. Med. Int. 27: 23-32.

Pietta, PG (2000). Flavonoids as antioxidants. J. Nat. Prod. 63:1035-1042.

Poljsak, B;_Suput, D; Milisav, I (2013). Achieving the balance between ROS and antioxidants: when to use the synthetic antioxidants. Oxid. Med. Cell. Longev. 13: 24-33.

Sasse, A; Colindres, P; Brewer, MS (2009). Effect of natural and synthetic antioxidants on the oxidative stability of cooked, frozen pork patties. J. Food Sci. 74: 30-35.
Sharma, B; Singh, S; Siddiqi, NJ (2014). Biomedical implications of heavy metals induced imbalances in redox systems. Bio. Med. Res. Int. 26: 54-65.

Ujowundu, CO; Okwu, GN; Achilike, JJ; Nwaogu, LA; Ene, AC; Iheme, C (2017). Lead-induced oxidative stress and chemoprotective role of dietary supplements on wistar albino rats. Ann. Res. Rev. Biol. 13(6): 1-14.

Valko, M; Morris, H; Cronin, MTD (2005). Metals, toxicity and oxidative stress. Curr. Med. Chem. 12(10):1161-1208. 